\title{
Evaluation of combustion characteristic of charcoal from different tropical wood species
}

\author{
Ijagbemi Christiana. $\mathrm{O}^{\mathrm{a}}, P h D$,Adepo $\mathrm{S}$. Olusegun ${ }^{\mathrm{b}}$ andAdemolaKazeem $\mathrm{S}^{\mathrm{c}}$. \\ ${ }^{\mathrm{a}, \mathrm{c}}$ Department of Mechanical Engineering, Federal University of Technology, Akure, Nigeria \\ ${ }^{\mathrm{b}}$ Department of Mechanical Engineering Technology, Rufus Giwa Polytechnic, Owo, Nigeria
}

\begin{abstract}
The combustion characteristics of charcoal produced from wood offcuts of some selected tropical wood species (Iroko, Obeche, Oak, Afara, and Mahogany) were evaluated. The woods offcuts were collected from different saw-mills in Ibadan metropolis, Nigeria and were converted into charcoal using a portable steel kiln. Physicalproperties such as density and proximate analysis i.e. percentage moisture content (PMC), percentage volatile matter (PVM), percentage ash content (PAC), percentage fixed carbon (PFC) and heating values (HV), of the produced charcoal were determined using the American Standard Testing Method (ASTM D1102-56). Analysis of wood and production of charcoal were carried out at the Forestry Research Institute of Nigeria Jericho Ibadan, Oyo State while determination of densities and the proximate analysis tests on the charcoal samples were carried out at the Forestry and Wood Department Laboratory, Federal University of Technology, Akure.
\end{abstract}

Keywords: - Characteristic, Charcoal, Percentage, Evaluation

\section{INTRODUCTION}

Traditionally, energy in the form of firewood, twigs and charcoal have been the major sources of renewable energy for many developing countries. Although Africa accounts for $12 \%$ of the global population, it consumes only $4 \%$ of global energy. The high and rapid demand for wood fuel consumption is considered as a major contributing factor to the fuel wood crisis in Nigeria[1]. The demand for fuel wood is expected to have risen to about $213.4 \times 10^{3}$ metric tonnes, while the supply would have decreased to about $2.84 \times 10^{2}$ metric tonnes by the year 2030. For this reason, a transition to a sustainable energy system is urgently needed in the developing countries such as Nigeria. One of such energy sources is wood waste or sawmill residue. Wood offcut constitutes one of the most abundant waste or residue in wood industries. It was estimated that wood waste generated in the country in 1998 was 1.72 million $/ \mathrm{m}^{3}$ out of which wood off cuts was $15 \%$.

Charcoal made from materials such as wood offcut and partially decomposed plant waste can be an alternate source of domestic and industrial energy to briquettes, firewood, gas, coal and electricity. Presently, the major source of energy to the rural community is fuelwood because other sources of energy (electricity, gas and kerosene) are either not available or grossly inadequate where available and they are beyond the reach of the masses. Depending on the type of wood offcut used to make charcoal, they burn cleaner in cook stoves than briquettes and firewood. Charcoal production from wood offcuts thereby turns wood waste materials into fuel source whichwould serve as an alternative to non-renewable energy resources.

. However, inefficient wood conversion and low biomass recovery from the timber process in Nigerian forest industry have led to the prevalence of wood wastes around sawmills, thereby constituting a visual blight to the local environment and a breeding ground for wood decaying organisms. But, these hills of wood off cut could be converted into charcoal for fuel energy supply. [2] Charcoal made from wood off cut can reduce forest degradation and deforestation to mitigate these problems. According to [3], one of the promising solutions to the problems of unutilized agricultural residues and wood waste is the application of charcoal production technology by knowing which wood specie has the highest heating value and low ash content.

[4] and [5] described the desirable criteria for quality wood charcoal as having low moisture content, relatively easy to cut, easy to handle, easy to ignite and burn with high calorific value/heating value, producing very little or no smoke without toxic fumes and neither spits nor sparks. They retain grain of the wood; it has jet black colour with shining luster; it is sonorous with metallic ring and does not soil the finger. These criteria are found in many tropical woodspecies and other woody species. [5]examined some Acacia wood species for their potential of charcoal production and gross heat of combustion. The results obtained indicated that charcoal from Acacia wood species had density ranges from 0.563 to $0.90 \mathrm{gcm}^{-3}$, with heating value of $32.39 \mathrm{MJkg}^{-1}$, percentage fixed carbon of $84.70 \%$ and low ash and volatile matter of $3.35 \%$ and $11.95 \%$ respectively. The results obtained were more or less close to the desirable criteria for quality charcoal. [6]suggested apparent density of 0.4 to $0.9 \mathrm{gcm}^{-3}$ for efficiency of quality charcoal. 
[7] reported a density of 0.621 and $0.623 \mathrm{gcm}^{-3}$ for charcoal produced from wood of six years old A. amplecipsandA. karroo respectively, the two charcoal samples used had gross heat of combustion values of $7,032 \mathrm{Calg}^{-1}$ and $6,865 \mathrm{Calg}^{-1}$ respectively, percentage volatile matter of $28.23 \%$ and $29.11 \%$ respectively, moisture content values of $5.53 \%$ and $5.38 \%$, ash content values of $5.37 \%$ and $6.42 \%$ respectively and fixed carbon values of $60.87 \%$ and $56.92 \%$ respectively. According to [8], calorific properties of the charcoal produced showed that charcoals from tropical wood species are very suitable for charcoal production. The efficiency from the use of different wood for charcoal production has been demonstrated by many researchers, charcoal produced from Afezelia Africana had the best physical and combustion properties when compared with those produced from Meliciaelcelsa and Acacia salicina which had lower combustion properties. According to the research, a heating value of $31,460 \mathrm{~kJ} / \mathrm{kg}$, percentage fixed carbon of $86 \%$, ash content of $6.2 \%$ and volatile matter of 9.4\% were obtained for charcoal produced from Afezeliaafricana[8].

[5], produced charcoal from Acacia asak and Acacia negrii and obtained relatively high calorific values that ranged between 6,763 $\mathrm{Calg}^{-1}$ and 6,865 $\mathrm{Calg}^{-1}$, with low ash content of between $3.22-5.2 \%$; relatively high volatile matter values that ranged between $27.55 \%$ and $31.56 \%$ with fixed carbon content between $57.89 \%$ and $62.63 \%$. The results showed that charcoal produced from Acacia wood species have higher calorific values than those produced using soft wood species such as spruce. This may be due to the density of wood species used, which is higher than that of spruce or any other soft woods species.

[9],reported aheating value of $23.43 \mathrm{MJ} / \mathrm{kg}$ for charcoal produced from Mangiferaindica. According to DIN 51731 , a minimum value of $17,500 \mathrm{~kJ} / \mathrm{kg}$ must be obtained before a biomass material can be regarded as having adequate calorific value. The percentage ash content,and moisture content values obtained by [9], for Mangiferaindica are $7.26 \%$ and $8.06 \%$ respectively.[10]obtainedpercentage volatile matter values of 73.5 and $78.2 \%$ for charcoal produced from Elaeisguineensis. This was due to low carbonizationtemperature during its conversion to charcoal and this made the charcoal easier to ignite although burn with much smoke. [10]also obtained relatively low fixed carbon content values that ranged between $11.9 \%$ and $16.4 \%$; ash content values of between 4.33 and $7.26 \%$ and heating value of $21,420 \mathrm{~kJ} / \mathrm{kg}$ to $23,431 \mathrm{~kJ} / \mathrm{kg}$.

[11] obtained apparent density values of 0.292 and $0.325 \mathrm{gcm}^{-3}$ respectivelyon charcoal produced from Acacia stenopylla and Acacia seyal, and also recorded fixed carbon content values of 59.83\% and 58.76\%; volatile matter values of $27.28 \%$ and $28.08 \%$; high ash content values of $5.7 \%$ and $7.02 \%$ and gross heat of combustion values of $6,746 \mathrm{Calg}^{-1}$ and $6,590 \mathrm{Calg}^{-1}$ respectively.

\subsection{Charcoal Density}

\section{CHARACTERISTICS}

The densities of the charcoal samples were determined using water displacement method. Density was calculated from the ratio of the mass to the volume of the charcoal in accordance with the method used by[12].The densities were calculated using equation (1),

$\rho=\frac{\mathrm{m}_{\mathrm{c}}}{\mathrm{v}_{\mathrm{w}}}(1)$

where

$\rho=$ Density

$\mathrm{m}_{\mathrm{c}}=$ Mass of charcoal sample $(\mathrm{g})$

$\mathrm{v}_{\mathrm{w}}=$ Volume of water displaced $\left(\mathrm{cm}^{-3}\right)$

\subsection{Percentage Moisture Content of Charcoal Samples}

The charcoal samples were weighed and then placed in oven for 24 hours at $103^{\circ} \mathrm{C}$, The PMC was estimated using,

$\% M C=\frac{W_{C}-D_{C}}{D_{C}} \times 100(2)$

where,

$W_{C}=$ Air dried weight of charcoal

$D_{C}=$ Oven dried weight of charcoal at $103^{\circ} \mathrm{C}$

$\mathrm{MC}=$ Moisture content.

2.3 Percentage Volatile Matter of Charcoal Samples (PVM)

The percentage volatile matter, PVM, was calculated using, 
$\% V M=\frac{M_{o d}-M_{s f}}{M_{o d}}$

where

$M_{o d}=$ Mass of oven dried sample of charcoal (g)

$M_{s f}=$ Mass of sample after $10 \mathrm{~min}$ in furnace at $550^{\circ} \mathrm{C}(\mathrm{g})$

\subsection{Determination of Percentage Ash Content of Charcoal Samples (PAC)}

Percentage ash content was calculated as a proportion of the dried weight of the ash residue in furnace to the oven-dried weight of charcoal specimen. This was determined using,

$\%$ Ash content $=\frac{M_{a r}(g)}{M_{o . d}(g)} \times 100$

where

$M_{a . r}=$ Mass of ash residue $(\mathrm{g})$
$M_{o d}=$ Mass of oven dried sample $(\mathrm{g})$.

\subsection{Percentage Fixed Carbon of the Charcoal Samples (PFC)}

The percentage fixed carbon, PFC was calculated by subtracting the sum of percentage volatile matter (PVM) and percentage ash content (PAC) from 100. The carbon content is usually estimated as a "difference", i.e., all the other constituents are deducted from 100 as percentages and the remainder is assumed to be the percentage of pure or fixed carbon [13]. This was determined using,

$\% F C=100-(\% V M+\%$ A.C $)$

where

$V M=\%$ Volatile matter

$\% A C=\%$ Ash content

$\% F C=\%$ Fixed carbon

\subsection{HEATING VALUE $(\mathrm{HV})$}

The calorific value (or heating value) is the standard measure of the energy content of a fuel.The Heating Value of the tropical hard wood charcoal samples were calculated using equation (6) below[4],

$\mathrm{HV}=2.326(147.6 \mathrm{C}+144 \mathrm{~V})(6)$

where

$\mathbf{C}=$ the percentage fixed carbon and

$\mathbf{V}=$ the percentage volatile matter.

\section{PERFORMANCE EVALUATION OF CHARCOAL SAMPLES}

The evaluation of combustion properties of the various charcoal samples produced was carried out through water boiling test. The procedure used in the calculations of the parameters was based on the approach used by [14].

\subsection{BurnRate (F)}

The burn rates $(\mathrm{F})$ corrected for moisture content of the various tropical wood charcoal in cook stove were calculated using the formula below,

$\mathbf{F}(\mathbf{k g} / \mathbf{h})=\frac{1}{t} \cdot \frac{100\left(W_{i}-W_{f}\right)}{(100+M)}(7)$

where

$\mathrm{F}=$ Burning Rate $(\mathrm{kg} / \mathrm{h})$

$W_{i}=$ Initial weight of the fuel before burning $(\mathrm{kg})$

$W_{f}=$ Weight of fuel after burning $(\mathrm{kg})$

$\mathrm{M}=$ Moisture content of the fuel 
$\mathrm{t}=$ Total time taken for burning fuel

3.2 Time Spent in Cooking Per Kilogram of Cooked Food

$T_{s}=\frac{\text { Total time spent in cooking }}{\text { Total weight of cooked food }} \quad(\mathrm{hr} / \mathrm{kg})$

where

$\mathrm{T}_{\mathrm{S}}=$ Timespent

\section{RESULTS AND DISCUSSION}

Charcoal from different wood species used for these analyses had densities ranged between $0.453 \pm$ $0.038 \mathrm{gcm}-3$ (Afara specie) and $0.620 \pm 0.046 \mathrm{gcm}-3$ (Obeche specie) $(P<0.05)$. The densitiesof charcoal produced from Iroko, Oakand Mahogany wood had density values of $0.5567 \pm 0.042 \mathrm{gcm}^{-3}$, $0.5300 \pm 0.035 \mathrm{gcm}^{-3}$ and $0.4567 \pm 0.032 \mathrm{gcm}^{-3}$ respectively, as shown in Fig.1(a). Charcoal produced from Afarawood had the least density $\left(0.4533 \pm 0.038 \mathrm{gcm}^{-3}\right)$ among the various charcoal samples used while Obeche wood specie had the highest density value. According to [6], these variations may be due to the differences in the age of trees species and/or the environmental conditions as a result of using different maximum final temperatures during carbonization process. However, density values reported in this study met at least in part, the criteria suggested by [7].

Significant differences in heating values were found among charcoal samples used $(\mathrm{P}<0.05)$. The highest value was obtained from charcoal of Afara $\operatorname{wood}\left(3.3236 \times 10^{4} \pm 171.932 \mathrm{kJkg}^{-1}\right)$, with a close heating value proportions with charcoal fromObeche wood $\left(3.3038 \times 10^{4} \pm 169.604 \mathrm{kJkg}^{-1}\right)$ and Oak wood $\left(3.2956 \times 10^{4} \pm 430.128 \mathrm{kJkg}^{-1}\right)$ while Mahogany wood had heating value of $\left(3.2230 \times 10^{4} \pm\right.$ $337.054 \mathrm{kJkg}-1)$ andIrokowood had the least heating value of $(3.2149 \times 104 \pm 248.974 \mathrm{kJkg}-1)$. These are as shown in Fig. 1(b). The varying heating values observed was as results of low ash content and high fixed carbon content in charcoal which are associated with high lignin content in the wood used [15].Afara wood had the highest lignin content while Iroko wood specie had the least lignin content among the wood samples used to produced charcoal. This fact is related to the higher resistance to thermal degradation of lignin, when compared to holocelluloses, mainly due to the increasing number of $\mathrm{C}-\mathrm{C}$ and $\mathrm{C}=\mathrm{C}$ present in its structure and also because lignin has higher percentage of elemental carbon and low oxygen, when compared with other chemical components of wood [15]. The results obtained for heating values in this study are higher than the values obtained by [6], for charcoal from acacia tree species. This may also be due to differences in ages of trees used for charcoal production and the peak temperatures during the carbonization process. However, the heating values reported in this study met at least in part, the criteria suggested by [7] for wood charcoal.

Chemical properties of charcoal showed significant differences among the various species of charcoal used for these analyses. Charcoal produced from Oak wood has significantly the highest moisture content value of $(4.823 \pm 0.954 \%)$, charcoal from Irokowoodspecie had(3.820 $\pm 0.931 \%)$,charcoal from Mahogany wood specie had $(3.733 \pm 1.106 \%)$; charcoal from Obechewoodspecie had $(2.663 \pm 0.448 \%)$ while charcoal from Afara wood had the lowest moisture content of $(2.110 \pm 0.661 \%)$. $(\mathrm{P}<0.05)$. Charcoal that had lower moisture content gave often-higher gross heat of combustion or heating values. This is because high moisture content lowers the calorific or heating value of charcoal [13]. This seems true when charcoal from Oak specieshad the highest moisture content value of $(4.823 \pm 0.954 \%)$ but had a lower heating valueof $\left(3.2956 \times 10^{4} \pm 430.128 \mathrm{kjkg}^{-1}\right)$; this was due to the water absorbing nature of oak tree and low level of halocelluloses in oak wood [8], while charcoal from Afara wood which had the lowest percentage moisture content value had the highest heating value of $\left(3.3236 \times 10^{4} \pm 171.932 \mathrm{kjkg}^{-1}\right)$.Fig.2(a) shows the variations in percentage moisture content of various charcoal samples used. The values of moisture content of charcoal produced from different tropical wood species used for these analyses fall within the desirable criteria by [13] in which $7 \%$ is the higher limit for moisture content.

Percentage volatile matter in charcoal from Obechewoodspecie presented distinctly the highest proportion $(11.00 \pm 0.5000 \%)$ compared to others. Charcoal from Afara wood, Iroko and Oak wood had close percentage volatile matter proportions of $(7.833 \pm 1.155 \%),(7.833 \pm 1.607 \%)$ and $(7.167 \pm 2.082 \%)$ respectively, with Afara and Iroko species producing similar values of percentage volatile matter. Charcoal from Mahogany wood presented the lowest value of percentage volatile matter $(5.000 \pm 0.866 \%)$. $(\mathrm{P}<0.05)$. Fig. 2 (b) shows the variations among various charcoal samples used. The volatile matter in charcoal can vary from a high of $40 \%$ or more down to 5\% or less [13]. According to [16] regarding quality of charcoal, lower levels of volatiles in charcoal is associated with high level of lignin and low level of extractives in wood. This was responsible for Obeche wood specie which had more wood extractives among the various wood samples selected for the production of charcoal and Mahogany wood had the least. High volatile charcoal is easy to ignite but may burn with a smoky flame while low volatile charcoal is difficult to light and burns very cleanly. However, high 
volatile charcoal is preferable for some purposes such as barbecue, while other utilizations as chemical purification and metal manufacture need charcoal with low percentage volatile matter content.

There is significant difference in proportion of fixed carbon among charcoal samples used and the greatest proportion of fixed carbon was in Afara specie $(89.167 \pm 1.258 \%)$ which had close fixed carbon content values with charcoal samples from Mahogany specie and Oak specie $(89.000 \pm 0.500 \%)$ and $(89.000 \pm 2.291 \%)$ respectively.Charcoal from Iroko specie had fixed carbon content value of $86.000 \pm 0.866$ while the lowest was that of Obeche specie $(85.500 \pm 0.500 \%)$. $(\mathrm{P}<0.05)$. The variation in percentage fixed carbon content is shown in Fig. 5.3(a). The fixed carbon content of charcoal ranges from a low of about 50\% to a high of around $95 \%$ [13], thus charcoal consists mainly of carbon. Charcoal produced from Afarawoodwhich had the highest heating value also had the highest percentage fixed carbon content value except that of Obeche which had a higher heating value and the lowest percentage fixed carbon in this present study. According to [15] on quality of charcoal, better chemical properties of charcoal such as higher level of fixed carbon is also associated with high levels of lignin and low level of holocelluloses and extractives in wood. Proportion of fixed carbon content can be controlled through the maximum temperature and its residence time during the carbonization process [17]. Increasing the fixed carbon content of charcoal in such a way is associated always with decrease in charcoal yield.

The percentage Ash content in various wood charcoal used for these analyses were significantly different $(\mathrm{P}<0.05)$. Charcoal from Iroko wood $(6.167 \pm 0.764 \%)$ had the highest value and a close proportion of ash content value with charcoal from Mahogany wood $(6.000 \pm 1.000 \%)$, while charcoal from Oak, Obeche and Afara wood species had ash content proportions of $(3.833 \pm 1.258 \%),(3.500 \pm 0.500 \%)$ and $(3.000 \pm 0.500 \%)$ respectively. The variation in percentage ash content of charcoal samples used is shown in Fig.3(b). The present study showed that charcoal samples with lower ash content value has invariably higher heating values, with Afara specie having the least ash content value while Iroko specie had highest ash content value. Charcoal sample from Afara wood produced least amount of ash because of its higher level of lignin and low mineral matter compared to charcoal from other wood species. According to [18], presence of high mineral matter components in wood is not desirable, because they are not degraded during carbonization and they remain in charcoal as an undesirable residue (ash) which also contributes to the reduction of charcoal heating value. Ash content of charcoal varies from about $0.5 \%$ to more than $5 \%$ depending on the species of wood used to produce the charcoal. Good quality lump charcoal typically has an ash content of about $3 \%$ [13].

Regression analysis was used to establish linear regression model from the values of correlation coefficient. The plot of the best straight line fit is shown in Fig.4, and the linear equation is:

$Y=34238-336.88 X ; R^{2}=0.999(9)$

where

$Y=$ Heating Value,

$\mathrm{X}=$ percentage Ash content

The linear regression model developed shows an increase in heating value as the percentage ash content of the charcoal samples decreases, Fig.4.

\section{CONCLUSION AND RECOMMENDATION}

This research work was carried out to evaluate the physical and combustion characteristics of charcoalproduced from wood offcuts of some selected tropical wood species. The combustion characteristics of charcoal used in this study was influenced by the properties of wood that was used. The quality of the charcoal that was produced using wood offcuts of Afara wood was higher than those of other species. It has the lowest percentage moisture content, ash content and highest heating value and it is followed by charcoal produced from obeche wood offcut. There was little variation in the qualities of charcoal from other wood species used in this study. However, all species of wood offcut used possess good combustion properties and had a high range of heating values.

The production and uses of charcoal from wood offcuts should be given wide publicity in Nigeria due to the imminent wood shortage and scarcity of other non-renewable energy sources.

\section{REFERENCES}

[1] Himraj, D,Environmental management, Vol. 19 (3),1993, 283-288.

[2] Wilaipon, P. American Journal of Applied Science. Vol. 4(2007), 995-998.

[3] Ogunsanwo, O. Y, Effective Management of Wood Waste for Sustainable Wood Utilization in Nigeria,27th Annual Conference of Forestry Association of Nigeria Abuja, FCT 17-21, Sept., 2001, pp225-234.

[4] Bailey, R.T. and Blankenhorn, P.R, Wood science, 15(1), (1984), pp19-18 
[5] Hines, D.A. and Eckman, K., Indigenous Multipurpose Trees of Tanzania: Uses and EconomicBenefits for People,FO: Misc/93/9 Working Paper, FAO, Rome, (1993)

[6] Megahed, M. M.; M. L. El-Osta; H. A. Abou-Gazia and A. M. El-Baha, Properties of plantation grownleguminous species and their relation to utilization in Egypt. Menofiya Journal of AgriculturalResearch23 (6), (1998), 1729-1751.

[7] Food and Agriculture Organization of the United Nations- FAO,Charcoal for domestic and industrialuse. FAO, Rome, (1962).

[8] Stimely, G. L. and Blankenhorn, P. R, Effects of species, specimen size and heating rate on charcoalyield and fuel properties. Wood and Fiber Sciences 17(4), (1985), 477-489.

[9] Massey, E. E. and Prima, S. D, The demand for charcoal in Dares Salaam Tanzania: An economicand environmental assessment. PREM report.(2005)

[10] Antal, M. J, Process for charcoal production from woody and herbaceous plant materials, US pat,(1995), $5435 \& 983$

[11] Aref, I. M., El-Juhany, L. I. and HegazyS. S Comparison of the growth and biomass production ofsixAcacia species in Riyadh, Saudi Arabia after four years of irrigated cultivation. Journal of Arid Environments 54 (4),(2003), 783-792.

[12] Rabier, F., Temmerman, M., Bohm, T., Hartmann, H., Rathbauer, J. and Fernandez, M, Particledensity determination of pellets and charcoal. Journal ofBiomass and Bioenergy.30,(2006), 954- 963

[13] Food and Agriculture Organization of the United Nations- FAO, Industrial charcoal making, FAOForestry Paper No. 63, FAO, Rome.(1985)

[14] Ahuja, D. R., Joshi, V., Smith, K. R. and Venkataranman, C, Thermal Performance and Emission Characteristics of Unvented Biomass - Burning Cookstoves; A Proposed Standard Method for Evaluation of Biomass, . (1987), 12.

[15] Santos, R. C., Carneiro, A. D. and Castro, A. F, Correlation of quality parameters of wood and charcoal of clones of eucalyptus," Forest Sciences, No. 90, (2011) 221-230.

[16] Oliveira, E, Correlations between quality parameters of Eucalyptus grandis (Whill ex-Maiden) woodand charcoal, Technical Bulletin SIF 2, (1990).

[17] Hindi, S. S, Charcoal properties as affected by raw material and charcoaling parameters. M.Sc.Thesis, Alexandria University, Egypt,(1994)

[18] Tsoumis, G., Science and Technology of Wood: Structure, Properties, Utilization, Van Nostr and Rein old, New York, NY, USA.(1991) 


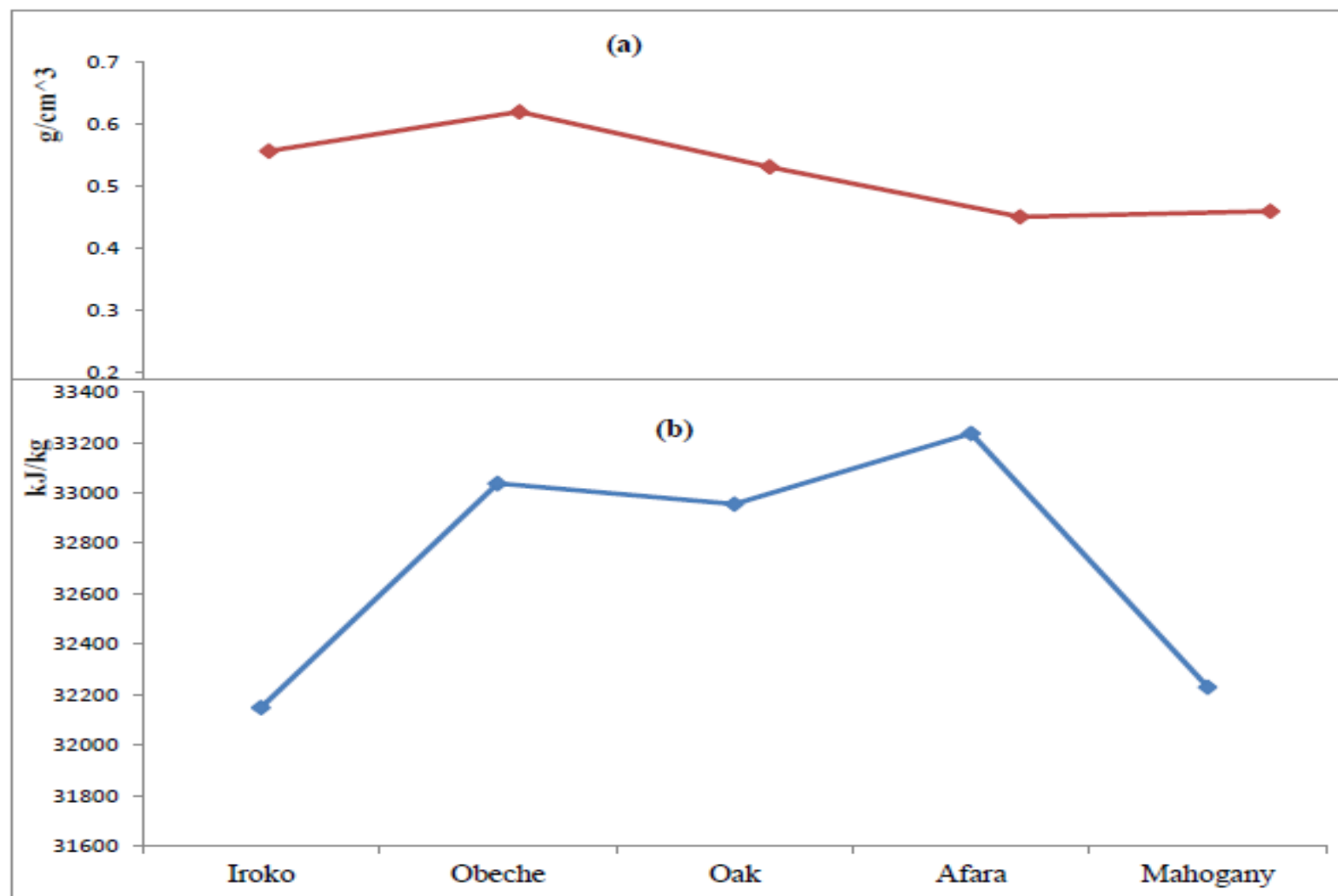

Figure 1.1: Variation in Density (a), Variation in Heating Values (b) of Charcoal Samples used.

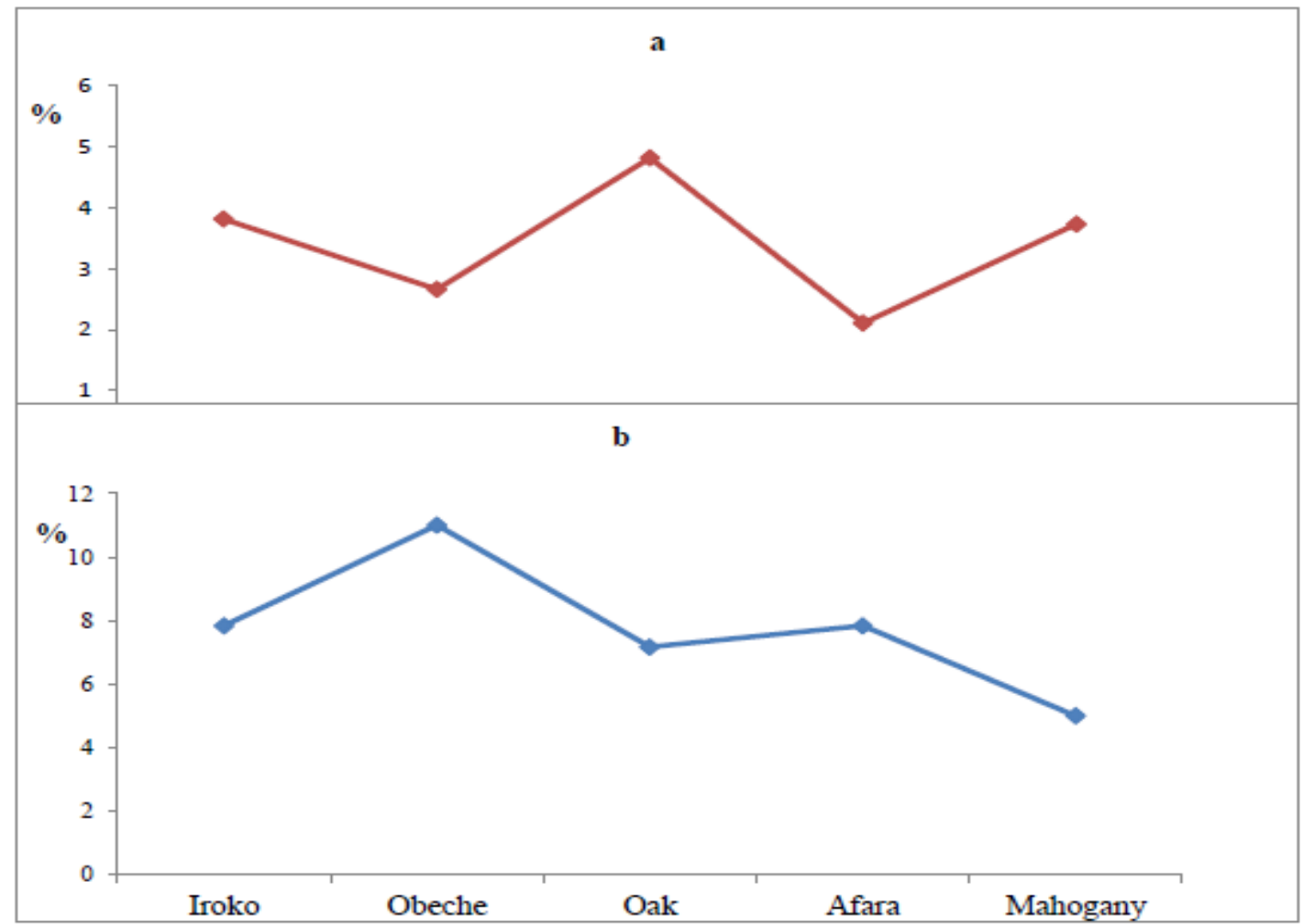

Figure 2: Variation in Percentage Moisture Content (a), Variation in Percentage Volatile Matter (b), of Charcoal Samples used. 


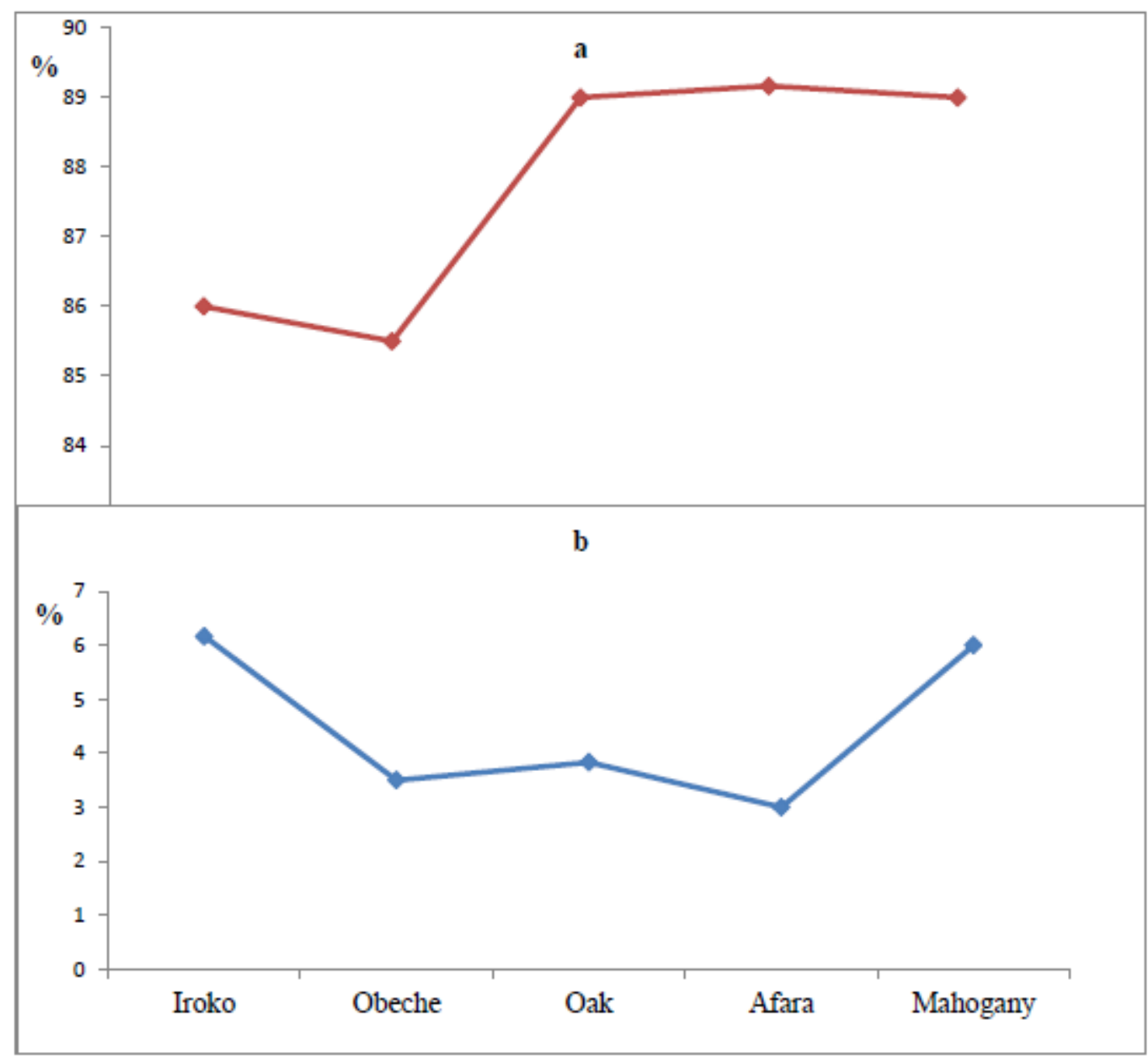

Figure 3: Variation in Percentage Fixed Carbon Content (a), Variation in Percentage Ash Content (b) of Charcoal Samples used.

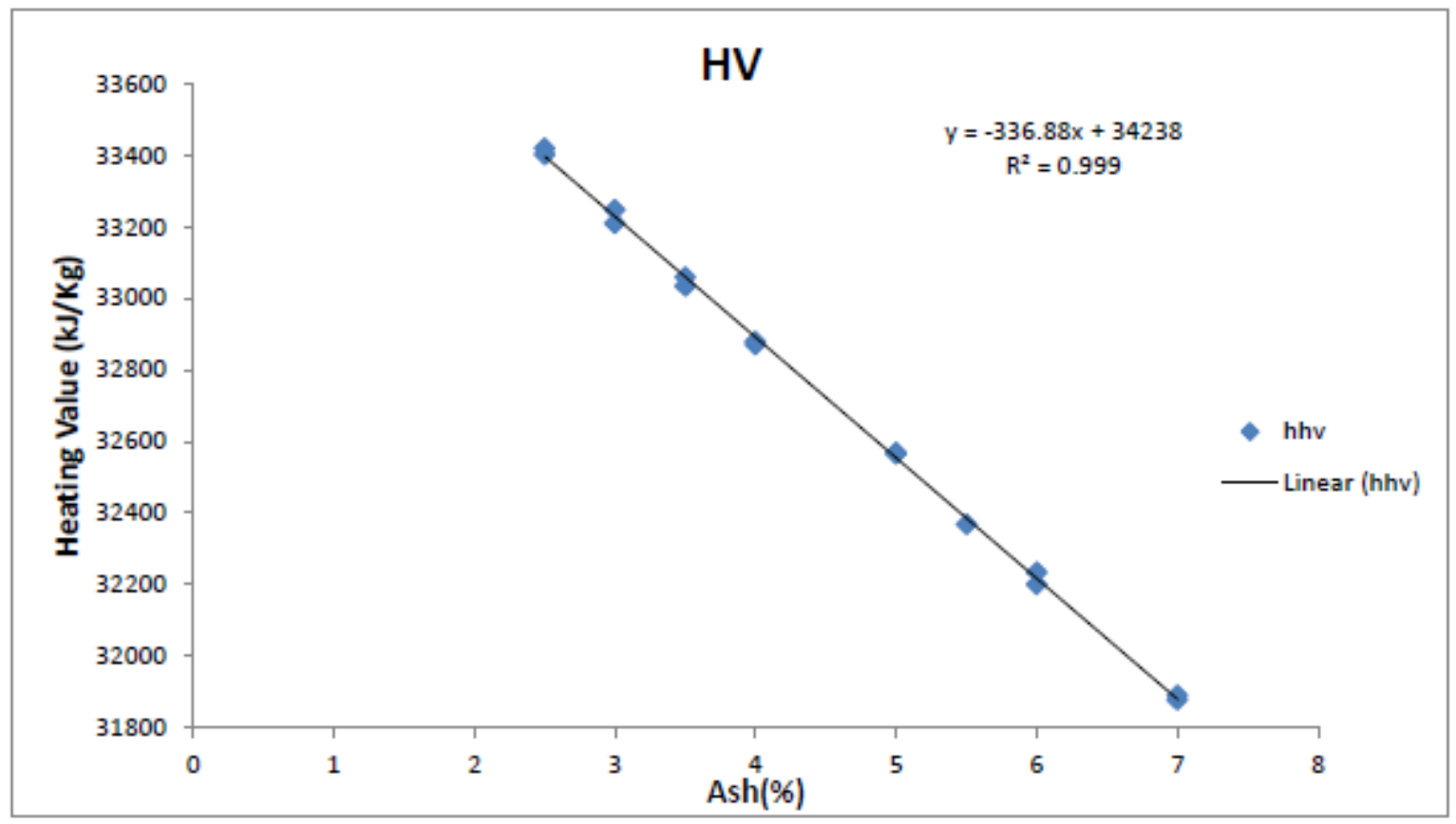

Figure 4: Linear Regression Graph of Heating Values and \% Ash 